\title{
Analysis of illicit ecstasy tablets: implications for clinical management in the accident and emergency department
}

\author{
K Sherlock, K Wolff, A W M Hay, M Conner
}

\begin{abstract}
Objective-To examine the composition of illicitly manufactured "ecstasy" tablets sold on the UK drugs market. Methods-Analysis by gas chromatography of 25 illicit ecstasy tablets handed in under amnesty to Leeds Addiction Unit. Results-Illicitly manufactured ecstasy tablets contain a range of ingredients, of widely differing concentrations, and even tablets with the same brand name have variable concentrations of active ingredients. Concentrations of 3,4-methylenedioxymethamphetamine (MDMA) more popularly known as ecstasy, varied 70 -fold between tablets. Nine tablets contained neither MDMA nor related analogues.

Conclusions-These results have implications for emergency workers attending to those who have become casualties of the drug ecstasy. Those claiming to have ingested ecstasy may actually have taken other agents that require different clinical management.
\end{abstract}

(F Accid Emerg Med 1999;16:194-197)

Keywords: ecstasy; MDMA; tablet constituents; dance drugs

Over the last decade data from surveys of the general population and in both school and university samples have indicated that the use of illicit drugs has increased, particularly among the young. ${ }^{1-7}$ Some have attributed this general increase to specific increases in the use of drugs such as amphetamines, "ecstasy", and LSD, commonly referred to as "dance drugs" or "recreational drugs". ${ }^{89}$ While drugs such as LSD and amphetamines have a well documented history, ${ }^{10}$ comparatively little is known Ethnicity and Health Unit, Faculty of Health, Harrington Building, University of Central Lancashire, Preston PR1 2HE K Sherlock

Division of Clinical Sciences, School of Medicine, University of Leeds $\mathrm{K}$ Wolff

A W M Hay

School of Psychology, University of Leeds M Conner

Correspondence to: Dr Sherlock.

Accepted 11 February 1999 about recreational use of ecstasy in the UK. Even less is known about the compositions of tablets sold as ecstasy.

In its pure form, the street drug ecstasy contains the active ingredient 3,4methylenedioxymethamphetamine (MDMA) but ecstasy by no means always contains MDMA. ${ }^{1-13}$ Since illegal drugs are typically produced in clandestine laboratories, there are few, if any, controls over their manufacture. Street samples of ecstasy could contain analogues of MDMA, other drugs, or no active ingredients. ${ }^{14}$ Buying ecstasy is a gamble, given that it exists in many forms, under different brand names sold at different prices. ${ }^{15}$ This paper describes the analysis of a range of tablets which are sold "on the street" as ecstasy and discusses the implications of the findings for health professionals.

\section{Method}

Twenty five ecstasy tablets handed in under an amnesty to the Leeds Addiction Unit were analysed under a Home Office licence in the Division of Clinical Sciences, School of Medicine, University of Leeds. ${ }^{16}$ Each of the tablets was photographed, weighed, crushed, and 10 $\mathrm{mg}$ of the crushed powder dissolved in deionised water before extraction using chloroform. Extracts of the drug in chloroform (10 $\mu l)$ were analysed by gas chromatography with flame ionisation detection. Samples were injected onto a silated glass $(1.5 \mathrm{~m} \times 4 \mathrm{~mm}$ internal diameter) column packed with $2 \%$ potassium hydroxide and $10 \%$ Apiezon $\mathrm{L}$ on Chromosorb-w-(AW) 100-120 mesh. Nitrogen at a flow rate of $60 \mathrm{ml} / \mathrm{min}$ was the carrier gas; hydrogen flow was at $1.0 \mathrm{~kg} / \mathrm{cm}^{2}$ and air flow $1.2 \mathrm{~kg} / \mathrm{cm}^{2}$. Analysis for the presence of amphetamine, methylamphetamine, methyldioxyamphetamine (MDA), MDMA, methyldioxyethamphetamine (MDEA), and a range of other drugs took place over a temperature gradient held at $155^{\circ} \mathrm{C}$ for $10 \mathrm{~min}$ followed by an increase of $8^{\circ} \mathrm{C} / \mathrm{min}$ to a final temperature of $195^{\circ} \mathrm{C}$. Temperatures of the injection and detector ports were $200^{\circ} \mathrm{C}$ and $190^{\circ} \mathrm{C}$ respectively. Extracts of tablets and quality control samples were measured against known concentrations of standards $(10 \mu \mathrm{g} / \mathrm{ml})$ and the detector recalibrated after every 10th sample. Paracetamol and caffeine were assayed by enzyme colorimetric assay and ketamine by using an in-house gas chromatography-mass spectrometry procedure.

\section{Results}

Each of the ecstasy samples in the present study was in tablet form, except for one, rhubarb and custard, which was a red and yellow capsule containing powder. Weights and dimensions of the tablets varied (see table 1). Of the 25 tablets handed in, doves (small white tablets embossed with a dove shape on one side) were the most common $(n=7)$ and all contained MDMA (range 19-140 mg). One of these dove tablets also contained traces of caffeine. A further five tablets (love heart, MDMA tablet, New Yorker, purple heart, and the rhubarb and custard capsule) also contained doses of MDMA (range 2-105 mg). One of these five tablets (purple heart) contained traces of caffeine and another (MDMA tablet) contained $39 \mathrm{mg}$ of caffeine. The only capsule, 
Table 1 Analysis of ingredients found in illicit ecstasy tablets

\begin{tabular}{|c|c|c|c|c|}
\hline \multirow[b]{2}{*}{ Tablet name } & \multicolumn{2}{|c|}{ Characteristics } & \multirow[b]{2}{*}{ Constituents } & \\
\hline & Size $(\mathrm{mm})$ & Weight (mg) & & \\
\hline & & & $M D M A$ (mg/tablet) & Stimulant (mg/tablet) \\
\hline Dove & $9 \times 4$ & 258 & 114 & \\
\hline Dove & $8 \times 4$ & 271 & 88 & \\
\hline Dove & $8 \times 4$ & 256 & 140 & \\
\hline Dove & $8 \times 4$ & 275 & 19 & \\
\hline Dove & $8 \times 3$ & 270 & 113 & \\
\hline Dove ( $1 / 2$ tablet $)$ & $8 \times 3$ & 148 & 55 & \\
\hline Dove (white) & $8 \times 3$ & 266 & 129 & Caffeine $(0.03)$ \\
\hline Love heart & $9 \times 3$ & 288 & 4 & \\
\hline MDMA tablet & $7 \times 4$ & 164 & 105 & Caffeine (39.0) \\
\hline New Yorker & $9 \times 2$ & 318 & 49 & \\
\hline Purple heart & $8 \times 2$ & 241 & 2 & Caffeine (0.02) \\
\hline \multirow[t]{2}{*}{$\begin{array}{l}\text { Rhubarb and custard } \\
\text { (red and yellow capsule) }\end{array}$} & Powder & 277 & 94 & $\begin{array}{l}\text { Amphetamine }(0.8) \\
\text { Methamphetamine (1.8) }\end{array}$ \\
\hline & & & $M D E A$ (mg/tablet) & Stimulant (mg/tablet) \\
\hline Adam \& Eve & $9 \times 2$ & 209 & 120 & \\
\hline California sunrise & $8 \times 3$ & 264 & 114 & Caffeine $(0.008)$ \\
\hline Dead on arrival & $8 \times 3$ & 306 & 94 & \\
\hline White burger & $13 \times 3$ & 507 & 125 & \\
\hline & & & Stimulant (mg/tablet) & Other (mg/tablet) \\
\hline Cox & $11 \times 3$ & 532 & Caffeine $(0.005)$ & \\
\hline Double diamond & $10 \times 1$ & 212 & $\begin{array}{l}\text { Amphetamine (19.0) } \\
\text { Caffeine (3.8) }\end{array}$ & \\
\hline Snowball & $7 \times 4$ & 223 & Caffeine (3.0) & Paracetamol (184) \\
\hline Snowball & $8 \times 4$ & 249 & Caffeine (0.13) & Paracetamol (55) \\
\hline Solid capsule & $2 \times 8 \times 7$ & 347 & & \\
\hline Strawberry milkshake & $13 \times 3$ & 693 & $\begin{array}{l}\text { Caffeine (7.8) } \\
\text { Ephedrine }\end{array}$ & Ketamine (197) \\
\hline Strawberry split & $13 \times 2$ & 552 & Caffeine (0.07) & Paracetamol (216) \\
\hline White lightning & $10 \times 3$ & 409 & Ephedrine & Ketamine (186) \\
\hline Whizz bomb & $11 \times 4$ & 490 & $\begin{array}{l}\text { Amphetamine (5.9) } \\
\text { Caffeine (10.0) }\end{array}$ & \\
\hline
\end{tabular}

Note: ketamine was detected using an in house gas chromatography-mass spectrometry assay (using selective ion monitoring). Ephedrine elutes at $9.55 \mathrm{~min}$ on the gas chromatography assay for ecstasy.

Paracetamol was assayed by enzyme colorimetric assay (limit of detection $0.01 \mathrm{mmol} / \mathrm{l}$ ).

rhubarb and custard, contained traces of both amphetamine and methamphetamine (see table 1). Four further tablets, Adam \& Eve, California sunrise, dead on arrival, and white burger, contained MDEA (range 94-125 mg), an analogue of MDMA. ${ }^{17}$ These tablets all contained MDEA with one also having a trace of caffeine (see table 1). Six other tablets contained stimulant substances other than MDMA or MDEA; two (double diamond and whizz bomb) had mixtures of amphetamine and caffeine, three (two snowball tablets and a strawberry split) had varying proportions of caffeine and paracetamol and one tablet with the name "Cox" embossed on it had a small trace of caffeine. One sample, a solid capsule, which had no brand name, had no detectable psychoactive ingredient. High doses of ketamine were identified in two tablets, strawberry milkshake and white lightning. These results are shown in table 1 .

COMPARATIVE ANALYSIS

The results of the present study were compared with three other reported analyses of illicit ecstasy tablets. ${ }^{11} 1218$ Some data were missing from these other analyses (such as tablet names and quantities of active ingredients). For comparative purposes, batches were split into the following categories: inactive dose (0-25 mg), small dose (26-75 mg), medium dose (76-125 mg), high dose (126-159 mg), and very high dose $(160 \mathrm{mg}+)$; see table 2 . The drugs MDMA and MDEA were grouped together, although it is acknowledged that there is a slight difference in their "optimum" dosages $^{17}$; the procedure followed for grouping dosages in this manner takes account of the lower reported potency of MDEA and the higher dosages of this drug required for an effect. Active doses for MDMA and MDEA are approximately $80-150 \mathrm{mg}$ and $100-200$ mg respectively. ${ }^{17}$ No information about dosage on a $\mathrm{mg} / \mathrm{kg}$ basis is available. MDMA and MDEA are similar in their effects and the risks associated with both will be similar. MDA was also grouped with MDMA and MDEA, since dosage concentrations for all but one of the tablets which contained MDA were under the optimum dose range (that is, below $80 \mathrm{mg}$ ).

Table 2 Comparison of dose concentrations in four batches of street samples of ecstasy; values are number (\%)

\begin{tabular}{|c|c|c|c|c|c|c|c|c|}
\hline \multirow[b]{2}{*}{ Research } & \multirow[b]{2}{*}{ Year } & \multicolumn{6}{|c|}{ Level of $M D M A, M D E A$, and other drugs } & \multirow[b]{2}{*}{ Tota } \\
\hline & & $\begin{array}{l}\text { Inactive } \\
0-25 \mathrm{mg}\end{array}$ & $\begin{array}{l}\text { Small } \\
26-75 \mathrm{mg}\end{array}$ & $\begin{array}{l}\text { Medium } \\
76-125 \mathrm{mg}\end{array}$ & $\begin{array}{l}\text { High 126-159 } \\
\text { mg }\end{array}$ & $\begin{array}{l}\text { Very high } \\
160 \mathrm{mg}\end{array}$ & $\begin{array}{l}\text { Other (that } \\
\text { is, ketamine) }\end{array}$ & \\
\hline Milroy et al $(1996)^{18}$ & 1992 & $8(62)$ & $4(30)$ & 0 & 0 & $1(8)^{\star}$ & 0 & 13 \\
\hline Bean and Pearson $(1993)^{11}$ & 1992 & $6(50)$ & $3(25)$ & $3(25)$ & 0 & 0 & 0 & 12 \\
\hline Present study (1994) & 1994 & $10(40)$ & $2(8)$ & $9(36)$ & $2(8)$ & 0 & $2(8)$ & 25 \\
\hline Saunders $(1995)^{12}$ & 1994 & $9(30)$ & $2(7)$ & $9(30)$ & $5(17)$ & $1(3)$ & $4(13)$ & 30 \\
\hline Category totals & & 33 & 11 & 21 & 7 & 2 & & 80 \\
\hline Percentages & & $(41.25)$ & (13.75) & $(26.25)$ & $(8.75)$ & $(2.5)$ & $(7.5)$ & 100 \\
\hline
\end{tabular}

${ }^{\star}$ Represents the single high dose MDA tablet $(186 \mathrm{mg})$. 
Table 3 Range of constituents contained in "ecstasy" tablets of the same name across three studies

\begin{tabular}{|c|c|c|c|}
\hline Tablet name & No & Range of constituents & Doset \\
\hline Dove & 12 & All MDMA & Low - very high \\
\hline Strawberry (various) & 4 & $\begin{array}{l}2 \text { inactive } \\
2 \text { ketamine }\end{array}$ & $\begin{array}{l}\text { N/A } \\
\text { N/A and high }\end{array}$ \\
\hline White burger & 3 & $\begin{array}{l}2 \text { inactive } \\
1 \text { MDEA, MDMA, MDA }\end{array}$ & $\begin{array}{l}\text { N/A } \\
\text { Low }\end{array}$ \\
\hline Snowball & 3 & $\begin{array}{l}2 \text { inactive } \\
1 \mathrm{MDA}\end{array}$ & $\begin{array}{l}\text { N/A } \\
\text { High }\end{array}$ \\
\hline California sunrise & 2 & $\begin{array}{l}1 \text { amphetamine } \\
1 \text { MDEA }\end{array}$ & $\begin{array}{l}\text { N/A } \\
\text { Medium }\end{array}$ \\
\hline Love heart & 2 & $\begin{array}{l}1 \text { amphetamine } \\
1 \text { MDMA }\end{array}$ & $\begin{array}{l}\text { Low } \\
\text { Low }\end{array}$ \\
\hline Adam \& Eve & 2 & $\begin{array}{l}1 \text { MDEA } \\
1 \text { MDEA }\end{array}$ & $\begin{array}{l}\text { Low } \\
\text { Medium to high }\end{array}$ \\
\hline Buffalo & 2 & $\begin{array}{l}1 \text { MDMA } \\
1 \text { MDEA }\end{array}$ & $\begin{array}{l}\text { High } \\
\text { High }\end{array}$ \\
\hline Yellow callie & 2 & $\begin{array}{l}1 \mathrm{MDMA} \\
1 \text { ketamine }\end{array}$ & $\begin{array}{l}\text { Medium } \\
\text { N/A }\end{array}$ \\
\hline
\end{tabular}

N/A where data is not available.

^Names not available in one study (Bean and Pearson, $1993^{11}$ ).

†Doses are the same categories as in table 2.

The one tablet with a high concentration of MDA is highlighted in table 2. A further category of "other" drugs included six tablets (from all four datasets) that contained ketamine. Table 2 shows the probability of purchasing street samples of ecstasy containing MDMA, MDEA, MDA, ketamine, or no psychoactive ingredients.

On the basis of this comparative analysis, ecstasy consumers are more likely to be sold an inactive tablet. Purchase of tablets with a very high dose of MDMA is the least likely occurrence for consumers. A third of all illicit samples in the comparative analysis contain a medium or high dose of MDMA, with a small proportion $(n=6 ; 7.5 \%)$ of the tablets containing ketamine.

COMPARING "BRAND" NAMES

Thirty eight different brand names for 68 separate tablets were identified in three studies (Bean and Pearson did not identify brand names $\left.{ }^{11}\right)$. Nine of the 38 names were cited more than once, with the most popular identified in table 3. Doves were the most consistent "street" tablet to contain MDMA with all 12 (from the various studies) containing MDMA. Eight of the 12 contained $80 \mathrm{mg}$ of MDMA or more (that is, they contained an active dose). Four of the eight contained doses of MDMA over $120 \mathrm{mg}$.

\section{Discussion}

Twelve of the 25 ecstasy samples in our own study contained MDMA with four tablets containing MDEA. No tablets in the present sample were found to contain MDA, the parent compound of MDMA. ${ }^{17}$ On the basis of our sampling, there is a $28 \%$ chance of buying an active dose of MDMA (dose above $80 \mathrm{mg}$ ), and a $16 \%$ chance of purchasing an active (or near active) dose of MDEA (dose above 94 $\mathrm{mg}$ ).

Our survey suggests that there are three main areas of concern for users of ecstasy. The first is the variability in tablet constituents. The second, variation in quantities of active ingredients, and the third, the variability of both ingredients and quantity in tablets with the same brand name.
Tablets are as likely to contain no active ingredients as they are to contain MDMA or MDEA. Contrary to user accounts, ${ }^{15}$ ecstasy tablets are unlikely to contain cocaine, heroin, or other opiates. Including these ingredients in tablets is unlikely to be economic for drug manufacturers of ecstasy. ${ }^{12}$ White tablets embossed with a dove appeared to be the most commonly sold products on the ecstasy market, ${ }^{15}$ as they were in our own sample. All the dove tablets we analysed had MDMA as the main active ingredient, but there was more than a sevenfold difference in the concentration of MDMA. Highly variable concentrations of MDMA and related compounds in tablets may cause problems, particularly for those who consume several tablets over a period of a few hours; coupled with a high degree of polydrug use on the dance drug scene, this is perhaps the biggest danger ecstasy users face.

"Brand" name does not provide any guarantee of either ingredient or concentration. Some brand names may be more popular with consumers than others, and used as a marketing ploy to suggest either tablets of good quality or particular ingredients. ${ }^{12} 151920$ Indeed, it has been reported that the popular name for MDMA was originally changed from "empathy" to ecstasy. Although the former is a more accurate description of the drug's effects, the latter was believed to sell better. ${ }^{21}$ Health education officials should publicise the dangers of using ecstasy tablets in recreational environments and a working knowledge of the street name of the range of tablets sold as ecstasy may be useful.

Our survey has some lessons for a number of health care professionals. For those in accident and emergency (A\&E) departments (where growing numbers of patients who have reportedly taken ecstasy are seen) it is important to note the range of agents that may be consumed as ecstasy. Most of the ecstasy tablets that we (and others) have analysed contained MDMA or some other analogue. For patients admitted to $A \& E$ departments after an ecstasy overdose, it is important to bear this in mind. Other ingredients in ecstasy tablets are less of a concern. The other two principal ingredients in the tablets we analysed were paracetamol and ketamine. Paracetamol was not present in concentrations likely to cause harm, even if individuals took several tablets in one evening. Two of the 25 tablets we analysed contained the anaesthetic agent ketamine. The quantity of drug in the two tablets, $186 \mathrm{mg}$ and $197 \mathrm{mg}$ respectively, is equivalent to about $2.5 \mathrm{mg}$ ketamine $/ \mathrm{kg}$ body weight (for a $70 \mathrm{~kg}$ individual). Ketamine undergoes extensive first pass metabolism in the liver with the result that only about one sixth of an oral dose reaches the circulation. ${ }^{22}$ Ketamine is usually administered intramuscularly, and a dose of $0.5 \mathrm{mg} / \mathrm{kg}$ will alter the pain threshold, in other words, has some analgesic effect. This dose is similar to what would be obtained if someone swallowed either of the two ketamine containing tablets we analysed. One report even suggests that oral doses of $0.5 \mathrm{mg} / \mathrm{kg}$ will induce analgesia. ${ }^{23}$ 
However, others state that $0.5 \mathrm{mg} / \mathrm{kg}$ is not satisfactory for producing analgesia. ${ }^{22}$ Intramuscular injection of $10 \mathrm{mg} / \mathrm{kg}$ will produce anaesthesia for 10-25 minutes sufficient for surgery. Psychic sequelae appears to be dose related, ${ }^{24}$ and is reported to be markedly reduced if ketamine is used at subanaesthetic doses. ${ }^{23}$

Individuals would have to consume a number of the ketamine containing tablets we analysed before being rendered unconscious. However, the consumption of several tablets together may leave someone ataxic.

For health educators, there are several messages. Users of ecstasy are involved in a form of lottery with no guarantee that the tablets they purchase will contain MDMA (let alone a quantity sufficient to induce the experience they are seeking). The great variation in concentrations of active ingredients seems to present considerable risks for certain individuals. It is still unclear why a minority of users die after ingestion of just one or even several tablets of ecstasy. ${ }^{14}{ }^{18}$ Evidence points to some individual sensitivity to MDMA or its related analogues, and there is likely to be an increased risk for all concerned if several tablets are consumed in a short period of time. There is some limited evidence (only two cases) of differences between a male and a female in the metabolism of MDMA, with the MDA metabolite more rapidly cleared in a male than a female. ${ }^{25}$ Individuals given a racemic mixture of MDMA appear to metabolise the " $S$ " enantiomer more rapidly than the " $R$ " form. ${ }^{26}$

The tablets we analysed came from all parts of the UK and a number had ingredients other than MDMA or its analogues. None of these "non-ecstasy" tablets will provide an "ecstasy experience" and consumers should not take several tablets in the hope of achieving this state. This practice could result in consumption of a high dose of another drug (such as ketamine) which, by inducing a state of near anaesthesia, could result in a fall, or more significantly, an individual collapsing, apparently unconscious. Ecstasy users need to be reminded that there is no guarantee about the quality or likely effects of the drugs they consume.

Conflict of interest: none. Funding: none.
1 Leitner M, Shapland J, Wiles P. Drug usage and drugs prevention: the views and habits of the general public. London: HMSO, 1993.

2 Mott J, Mirlees-Black C. Self reported drug misuse in England and Wales: findings from the 1992 British Crime Survey. Research and Planning Unit paper 89. London: Home Office, 1995.

3 Balding J. Young people and illegal drugs in 1996. Exeter: Schools Health Education Unit, University of Exeter, 1996,

4 McMiller P, Plant M. Drinking, smoking and illicit drug use among 15 and 16 year olds in the United Kingdom. $B M \mathcal{F}$ 1996;313:394-7.

5 Parker H, Measham F, Aldridge J. Drug futures: changing patterns of drug use amongst English youth. London: Institute for the Study of Drug Dependence, 1995.

6 Ramsay M, Percy A. Drug misuse declared: results of the 1994 British Crime Survey. Research findings No 33. London: Home Office, 1996

7 Webb E, Ashton CH, Kelly P, et al. Alcohol and drug use in UK university students. Lancet 1996;348:922-5.

8 Anderson $\mathrm{K}$. The use and misuse of ecstasy (MDMA) in Scotland: a pilot study. Final unpublished report. Edinburgh Scottish Office, Department of Health, 1994.

9 Parliamentary Office of Science and Technology. Common illegal drugs and their effects; cannabis, ecstasy, amphetamines and LSD. London: POST, 1996.

10 Weil A, Rosen W. From chocolate to morphine. Everything you need to know about mind altering drugs. Boston/New York: need to know about mind

11 Bean P, Pearson Y. Ecstasy: supply and use. Report on a research study for "Businesses Against Drugs". Loughborough: Loughborough University, 1993.

12 Saunders N. Ecstasy and the dance culture. London: Neals Yard Desktop Publishing Studio, 1995.

13 Jansen KLR. Adverse psychological effects associated with the use of ecstasy (MDMA), and their treatment. In: Saunders N, ed. Ecstasy reconsidered. Exeter: BPC Wheatons, 1997: 112-33.

14 Henry J, Jeffreys $K$, Dawling $S$. Toxicity and deaths from 3,4-methylenedioxymethamphetamine. Lancet 1992;340 384-6.

15 Forsyth AJM. Ecstasy and illegal drug design: a new concept in drug use. International fournal of Drug Policy 1995;6: 193-209.

16 Wolff K, Hay AWM, Sherlock K, et al. Contents of "ecstasy". Lancet 1995;346:1100-1.

17 Shulgin A, Shulgin A. PIHKAL. A chemical love story. Berkeley, CA: Transform Press, 1991.

18 Milroy CM, Clark JC, Forrest ARW. Pathology of deaths Milroy CM, Clark JC, Forrest ARW. Pathology of deaths
associated with "ecstasy" and "eve" misuse. $\mathcal{F}$ Clin Pathol associated with "

19 Newcombe $R$. The use of ecstasy and dance drugs at rave parties and night-clubs. Some problems and solutions. Liverpool: ties and night-clubs. Some problem

20 Saunders N. Ecstasy reconsidered. Exeter: BPC Wheatons, 1997.

21 Eisner B. Ecstasy: the MDMA story. Berkeley, CA: Ronin 1993.

22 Clements JA, Nimmo WS, Grant IS. Bioavailability, pharmacokinetics, and analgesic activity of ketamine in humans. F Pharm Sci 1982;71:539-42.

23 Grant IS, Nimmo WS, Clements JA. Pharmacokinetics and analgesic effects of IM and oral ketamine. Br f Anaesth 1981;53:805-9.

24 Dundee JW, Bovill JG, Knox JWD, et al. Ketamine as an induction agent in anaesthetics. Lancet 1970;i:1370-2.

25 Helmlin HJ, Bracher K, Bourquin D, et al. Analysis of 3,4methylenedioxymethamphetamine (MDMA) and its memethylenedioxymethamphetamine (MDMA) and its metabolites in plasma and urine by
$\mathcal{A}$ Anal Toxicol 1996;20:432-40.

26 Lanz M, Brenneisen R, Thormann W. Enantioselective determination of 3,4-methylenedioxymethamphetamine and two of its metabolites in human urine by cyclodextrinmodified capillary zone electrophoresis. Electrophoresi 1997;18:1035-43. 